\title{
Carcass characteristics and meat quality of heavy swine fed different citrus pulp levels
}

[Características de carcaça e qualidade da carne de suínos com elevado peso de abate, alimentados com dietas contendo diferentes níveis de polpa cítrica]

\author{
P.H. Watanabe ${ }^{1}$, M.C. Thomaz ${ }^{2}$, U.S. Ruiz ${ }^{3}$, V.M. Santos $^{4}$, G.C. I. Masson ${ }^{4}$, A.L. Fraga, \\ L.A.F. Pascoal ${ }^{1}$, R.A. Robles-Huaynate ${ }^{6}$, S.Z. Silva ${ }^{6}$ \\ ${ }^{1}$ Universidade Federal da Paraíba - UFPB - Bananeiras, PB \\ ${ }^{2}$ Universidade Estadual Paulista - UNESP - Jaboticabal, SP \\ ${ }^{3}$ Universidade Estadual Paulista - UNESP - Dracena, SP \\ ${ }^{4}$ Aluno de pós-graduação - UNESP - Jaboticabal, SP \\ ${ }^{5}$ In memoriam \\ ${ }^{6}$ Zootecnista - UNESP - Jaboticabal, SP
}

\begin{abstract}
An assay with 36 swine initially weighting $83.7 \pm 5.1 \mathrm{~kg}$ body weight (BW) was carried out to evaluate the effects of the use of different dietary citrus pulp levels, $0,10 \%, 20 \%$, and $30 \%$, upon digestive organs weights, carcass characteristics, and meat quality of animals subjected to qualitative feed restriction program, and slaughtered at $130 \mathrm{~kg} \mathrm{BW}$. Linear response $(\mathrm{P}<0.05)$ on the weight of stomach, colon, and liver were observed. Negative linear responses $(\mathrm{P}<0.05)$ on final $\mathrm{BW}$ and carcass yield relative to citrus pulp addition to the diet were observed. Although a negative linear effect $(\mathrm{P}<0.05)$ of increasing dietary levels of citrus pulp had been observed on ham weight, yield of this by product was not affected $(\mathrm{P}>0.05)$. Higher levels of citrus pulp neither decreased backfat thickness nor increased amount of lean meat, indicative that qualitative feed restriction was not efficient. Positive linear effect $(\mathrm{P}<0.05)$ on $\mathrm{pH}$ measured 24 hours after slaughter and negative linear effect $(\mathrm{P}<0.05)$ on color characteristics as function of citrus pulp dietary levels were verified. Citrus pulp addition in qualitative feed restriction program may not be effective. As no deleterious effects upon meat qualities were observed, citrus pulp can be used as an alternative feedstuff for finishing swine.
\end{abstract}

Keywords: swine, carcass typification, feed restriction, soluble fiber

\section{RESUMO}

Foi realizado um ensaio utilizando 36 suínos machos castrados, com peso inicial de 83,7士5,1kg, para avaliar o efeito da inclusão de polpa cítrica, 0, 10, 20 e 30\%, em um programa de restrição alimentar qualitativa para suínos abatidos aos $130 \mathrm{~kg}$ de peso, sobre o peso dos órgãos do sistema digestório e sobre características da carcaça e da qualidade da carne. A inclusão de polpa cítrica proporcionou aumento linear $(P<0,05)$ nos pesos do estômago, cólon e fígado, e efeito quadrático $(P<0,05)$ no peso do ceco. Foi observada redução linear $(P<0,05)$ no peso, no rendimento da carcaça e no peso do pernil, porém não houve efeito $(P>0,05)$ sobre o rendimento do pernil. Maior inclusão de polpa cítrica não foi suficiente para reduzir a espessura do toucinho $e$ aumentar a quantidade de carne magra na carcaça, mostrando que a restrição alimentar qualitativa não foi eficiente. Foi observado aumento linear $(P<0,05)$ do $\mathrm{pH}$ da carcaça resfriada e linear negativo $(P<0,05)$ sobre as variáveis indicativas de cor da carne em função da inclusão da polpa cítrica nas dietas. A adição de polpa cítrica em programas de restrição alimentar qualitativa não foi eficiente. Por não promover nenhum efeito deletério sobre as características da carne, a polpa cítrica pode ser utilizada como ingrediente alternativo para suínos em terminação.

Palavras-chave: suíno, fibra solúvel, restrição alimentar, tipificação de carcaça

Recebido em 6 de outubro de 2009

Aceito em 30 de julho de 2010

E-mail: pedrowatanabe@cchsa.ufpb.br 


\section{INTRODUCTION}

Since its implementation in 90's, electronic typification of pork carcasses has contributed enormously to swine production sector for the benefit of consumers, offering commercial products with better appearance and quality (Silveira, 2003). Using this system, carcasses receive higher bonus according to their percent of lean meat disqualifying those with high fat contents (Fávero et al., 1997). Development of new presentations and commercial cuts of products have led industries to search heavier carcass from animals weighing around $130 \mathrm{~kg}$ of body weight, which in turn promote a decrease on operational cost of swine slaughter processes (Zagury, 2002).

However, finishing swine present high fat deposition (Whittemore, 1993), and slaughtering them at $130 \mathrm{~kg}$ of body weight (BW) without any prior nutritional management may result in low bonus return, reasons that do not justify this procedure.

Thus, it is necessary to adopt restriction program either qualitative or quantitative to feed swines heavier than $100 \mathrm{~kg}$ of body weight. For swine producers, qualitative feed restriction is more convenient since it implies only on energetic dilution of the ration by inclusion of fibrous ingredients, as residues of human food industries. Rice hulls from rice process industry (Fraga et al., 2009) as well as residues obtained from wheat processing plant (Lee et al., 2002), both tested on qualitative feed restriction programs, improved pork carcass characteristics. Other marketable subproducts can be used, but their nutritional effects should be attested.

Citrus pulp, a residue obtained from orange juice industry, is by far found at large amount in the State of São Paulo (Subprodutos..., 2006). It is an ingredient with high level of fibers, mainly soluble, and thus suitable to be used on qualitative feed restriction program for swine. Therefore, this study aimed to evaluate the effects of the utilization of different dietary levels of citrus pulp on weights of digestive organs, carcass characteristics, and meat quality of swine subjected to a qualitative feed restriction program.

\section{MATERIAL AND METHODS}

Thirty-six Topigs barrows with high capacity of lean deposition and weighing $80.4 \pm 2.7 \mathrm{~kg} \mathrm{BW}$ were allotted in individual pens $\left(2.55 \mathrm{~m}^{2}\right)$ equipped with semi-automatic feeders and communicating vessel drinkers.

Increasing levels of citrus pulp were added to the diets of animals distributed in four treatment groups during five days of adjustment before reaching the total amount of citrus pulp established in the trial protocol. Afterward, the experimental period started with barrows weighing $83.7 \pm 5.1 \mathrm{~kg}$ BW on average. Diets (Table 1) were formulated to meet requirements of barrows weighing $105 \mathrm{~kg} \mathrm{BW}$, high genetic potential for growth, and reared at a room temperature of $24^{\circ} \mathrm{C}$, as proposed by NRC (Nutrient..., 1998). The values of digestible energy (DE) and calcium of citrus pulp considered to formulate diets were $2,496.04 \mathrm{kcal} / \mathrm{kg}$ and $0.009 \%$, respectively.

Experimental treatments were: control diet corn-soy diet without citrus pulp; $\mathrm{Cp} 10$ diet formulated to have the same level of digestible Lys, $\mathrm{Ca}$, and non-phytate $\mathrm{P}$ of control diet, plus $10 \%$ of citrus pulp; Cp20 diet - formulated to have the same level of digestible Lys, Ca, and non-phytate $\mathrm{P}$ of control diet, plus $20 \%$ of citrus pulp; and Cp30 diet - formulated to have the same level of digestible Lys, $\mathrm{Ca}$, and non-phytate $\mathrm{P}$ of control diet, plus $30 \%$ of citrus pulp.

The proposed final $\mathrm{BW}$ to conduct the swine for slaughtering was $130 \mathrm{~kg}$ BW. After last weighing on the farm followed by $15 \mathrm{~h}$ of solid fast period, swine were re-weighed and slaughtered. Slaughtering procedure included stunning with electric charge, bleeding, scalding, scraping, and evisceration. Thereupon evisceration, organs of digestive system were collected and emptied. Stomach, small intestine, cecum, colon, liver, and pancreas were weighed. Longitudinal cut followed by weighing of half eviscerated carcasses were done. Half-carcass weight was expressed as percentage of live body weight. Processed dressed carcasses were then refrigerated at $4^{\circ} \mathrm{C}$ for $24 \mathrm{~h}$ for posterior evaluations. 
Table 1. Composition of experimental diets formulated to barrows with $105 \mathrm{~kg}$ body weight

\begin{tabular}{|c|c|c|c|c|}
\hline \multirow[b]{2}{*}{ Feedstuff, \% } & \multicolumn{4}{|c|}{ Diet } \\
\hline & Control & $\mathrm{Cp} 10^{(1)}$ & $\mathrm{Cp} 20^{(1)}$ & $\mathrm{Cp} 30^{(1)}$ \\
\hline Corn & 81.78 & 71.01 & 60.24 & 49.43 \\
\hline Soy meal & 16.40 & 17.17 & 17.94 & 18.75 \\
\hline Citrus pulp & 0.00 & 10.00 & 20.00 & 30.00 \\
\hline Limestone & 0.58 & 0.58 & 0.57 & 0.57 \\
\hline Dicalcium phosphate & 0.64 & 0.64 & 0.65 & 0.65 \\
\hline Salt & 0.30 & 0.30 & 0.30 & 0.30 \\
\hline Vitamin-mineral premix ${ }^{(2)}$ & 0.30 & 0.30 & 0.30 & 0.30 \\
\hline Total & 100.00 & 100.00 & 100.00 & 100.00 \\
\hline \multicolumn{5}{|l|}{ Calculated composition ${ }^{(3)}$} \\
\hline Digestible energy, $\mathrm{kcal} / \mathrm{kg}$ & 3,391 & 3,294 & 3,197 & 3,100 \\
\hline Crude protein, $\%$ & 14.87 & 14.28 & 14.37 & 14.48 \\
\hline $\mathrm{NDF}, \%^{(4)}$ & 11.88 & 12.61 & 13.33 & 14.06 \\
\hline $\mathrm{ADF}, \%^{(4)}$ & 4.23 & 5.35 & 6.46 & 7.57 \\
\hline NDSF, $\%^{(4)}$ & 7.41 & 10.95 & 14.63 & 18.04 \\
\hline Starch, $\%^{(4)}$ & 54.91 & 48.34 & 41.76 & 35.17 \\
\hline Digestible Lys, \% & 0.58 & 0.58 & 0.58 & 0.58 \\
\hline Digestible Met + Cys, \% & 0.46 & 0.43 & 0.41 & 0.38 \\
\hline Calcium, $\%$ & 0.44 & 0.44 & 0.44 & 0.44 \\
\hline Non-phytate phosphorus., $\%$ & 0.18 & 0.18 & 0.17 & 0.17 \\
\hline
\end{tabular}

${ }^{1}$ Citrus pulp on 10,20 , and $30 \%$ of inclusion.

${ }^{2}$ Vitamin premix - amount per kg of product: 2,500,000UI vitamin A; 500,000UI vitamin D3; 50mg biotin; 50mg choline; 10,000mg niacin; 3,000mg calcium pantotenate; 7mg vitamin B12; 1,800mg vitamin B2; 7,500mg vitamin $\mathrm{E}$; and 1,000mg vitamin K3. Mineral premix - amount per kg of product: 40,000mg Fe; 35,000mg Cu, 20,000mg Mn; 40,000mg Zn; 360mg Co; 840mg I; and 120mg Se.

${ }^{3}$ Nutritional composition according to Rostagno et al (2005).

${ }^{4} \mathrm{NDF}$ : neutral detergent fiber; ADF: acid detergent fiber; NDSF: neutral detergent-soluble fiber.

According to the Brazilian Method for Carcass Classification (Método..., 1973), the following evaluations of each right carcass were done: carcass length; backfat thickness measured at the first and last thoracic vertebrae, and last lumbar vertebra; loineye area, fat area; and fat/lean expressed as percentage of fat area relative to loineye area. Other carcass characteristics also measured were: weight of hot carcass without legs and head (HCW), backfat thickness (BT), and loin deep (LD) that was obtained between the last and penultimate ribs $6 \mathrm{~cm}$ far from the media dorsal line of right half carcass with the aid of a paquimeter to reproduce the use of a typification pistol. Taking into account HCW, $\mathrm{BT}$, and LD values, amount (LMA) and percent (LM\%) of lean meat were calculated according to equations proposed by Guidoni (2000). Bonification index (BI), that is a correction factor of the carcass value expressed as percentage, was determined using LM\% and HCW results as described by Fávero et al. (1997).

Arq. Bras. Med. Vet. Zootec., v.62, n.4. p.921-929, 2010
Longissimus and Semimembranosus muscles $\mathrm{pH}$ from right half carcass of each animal were determined 45min post mortem ( $\mathrm{pH} 45$ ') and on refrigerated carcass $(\mathrm{pH} 24 \mathrm{~h})$ maintained in cold chamber $\left(4^{\circ} \mathrm{C}\right)$ for $24 \mathrm{~h}$.

From the right half-carcasses, a 15-cm-tick chop of Longissimus muscle was sampled without adjacent fat. These samples were sent for physical analyses of meat. Objective colour measurements were taken on fresh meat using the Minolta Chroma-Meter, to record color as $\mathrm{L}^{*}, \mathrm{a}^{*}$, and $\mathrm{b}^{*}$ values. Other analyses included drip loss, water-holding capacity, WarnerBratzler shear force, and cooking loss. Also, a lipid oxidation assay was done by comparative analysis, observing the reactivity of the substances with 2-tiobarbituric acid (TBA) in samples stored in cold chamber for one and eight days after slaughtering, according to the method described by Pikul et al. (1989).

Four treatments with nine replications of one animal each were carried out according to a randomized block design to control differences on initial weight. Data formerly tested for 
normality of studentized residues (Cramer VonMises test at 5\%) were submitted to ANOVA, and processed with the aid of PROC GLM of SAS/1998 software, performed by linear multiple regressions until third degree. Final BW was used as covariate of all parameters analyzed in the statistical model.

\section{RESULTS AND DISCUSSION}

Addition of citrus pulp at different levels promoted an increase on weights of stomach, colon, cecum, and liver (Table 2), but did not on small intestine and pancreas weights $(\mathrm{P}>0.1)$. Table 3 presents prediction equations of these weights as function of citrus pulp levels.

Table 2. Mean values and coefficients of variation $(\mathrm{CV})$ of weights of digestive organs from swine fed different levels of citrus pulp

\begin{tabular}{lccccccc}
\hline \multirow{2}{*}{ Organ } & \multicolumn{4}{c}{ Level of citrus pulp, $\%$} & \multirow{2}{*}{ CV \% } & \multirow{2}{*}{ Regression } & \multirow{2}{*}{$\mathrm{P}$} \\
\cline { 2 - 5 } & 0 & 10 & 20 & 30 & & & 0.0013 \\
Stomach, g & 503.33 & 553.89 & 535.56 & 598.33 & 8.18 & Linear & 0.1 \\
Small intestine, g & $1,702.22$ & $1,725.00$ & $1,827.78$ & $1,904.44$ & 11.03 & - & $>0.13$ \\
Colon, g & $1,440.00$ & $1,541.11$ & $1,640.00$ & $1,913.89$ & 8.37 & Linear & $<0.0001$ \\
Cecum, g & 168.33 & 163.89 & 187.22 & 218.89 & 12.87 & Quadratic & 0.0314 \\
Pancreas, g & 162.22 & 156.11 & 175.00 & 176.11 & 10.53 & - & $>0.1$ \\
Liver, g & $2,187.80$ & $2,577.30$ & $3,097.80$ & $3,422.80$ & 12.04 & Linear & $<0.0001$ \\
\hline
\end{tabular}

Table 3. Prediction equations of weights of digestive organs from swine fed different levels of citus pulp

\begin{tabular}{lcccc}
\hline Variable & $\mathrm{b}_{0}$ & $\mathrm{~b}_{1}$ & $\mathrm{~b}_{2}$ & $\mathrm{R}^{2}$ \\
\hline Stomach, g & 545.66000 & +2.87200 & - & 0.42 \\
Colon, g & $1,445.50000$ & +15.88300 & - & 0.69 \\
Caecum, g & 144.02700 & -0.00096 & +0.00009 & 0.64 \\
Liver, g & 2.15500 & +0.00460 & - & 0.73 \\
\hline
\end{tabular}

A linear increase of stomach weight $(\mathrm{P}=0.0013)$ as consequence of the citrus pulp inclusion to the diet (Table 3) was observed. According to Low (1989), consumption of diet with high level of non-starch polysaccharides (NSPs) promotes an increase in gastric secretion resulting in highvolume-digesta due to their hydrophilic characteristics. So, the highest NSPs content, as the pectin of citrus pulp, higher should be the digesta volume in the stomach and hence the weight of the organ.

High levels of soluble NSPs cause hypertrophy of large intestine, local where microbial fermentations of these carbohydrates occur. As consequence of citrus-pulp increment to the diet, linear effect on colonic weight $(\mathrm{P}<0.0001)$ and quadratic effect on caecal weight $(\mathrm{P}=0.0314)$ were registered (Table 3). Higher corn level of control ration probably resulted in a diet with large amount of resistant starch whose physical characteristic inside the cecum is similar to NSP with respect to its fermentative potential (Kreuzer et al., 2002), what can explain the effect of CP10 ration upon this hindgut part. Addition levels of citrus pulp above 10\% determined higher caecal development which could be attributed to the great content of soluble NSPs in the diet. Pluske et al. (1998) also observed higher large intestine development from swine fed high level of soluble NSPs; they concluded that fermentation resultant short-chain fatty acids, mainly butyrate, were responsible for the higher cellular development of the colon mucosa.

Martelli et al. (1999) evidenced an increase on villus heights of caecal mucosa in swine averaging $160 \mathrm{~kg} \mathrm{BW}$ fed diets with $15 \%$ of sugar beet pulp silage. Wyatt et al. (1989) affirmed that ingredients that promote augmentation of the digesta viscosity, as the soluble fibrous fraction, cause higher wall activity of the large intestine for establishment of the gut peristaltism, leading to muscular hypertrophy and, as consequence, to higher cecum and colon weights.

Weight of pancreas was not affected $(\mathrm{P}>0.05)$, but liver showed higher development $(\mathrm{P}<0.0001)$ following the increment of citrus pulp levels to the diets (Table 3). Fraga et al. (2009) also observed an increase in liver weight of swine fed diets with rice hulls in feed restriction program. As the liver is the main local of energetic 
metabolism (Lehninger et al., 1995), where the major part of the synthesis of lipids and their lipoprotein carriers take place, activity highly depend on available energy (Bruss, 1997), it was expected a reduction of its weight as the levels of citrus pulp added to the diet increased. However, it is possible to explain the augmented liver sizes of animals fed citrus pulp since higher production and liberation of biliar salts may occur to adsorb the NSPs present in this ingredient. Sambrook (1981), evaluating inclusion of feedstuffs rich on soluble (barley) and non-soluble (cellulose) NSPs, observed that diets containing the highest level of soluble NSPs caused an increase on biliar salts production.

Data related to carcass characteristics of swine as function of dietary citrus pulp levels are indicated in Table 4. Table 5 presents those characteristics affected by the use of citrus pulp.

Table 4. Mean values and coefficients of variation (CV) of carcass characteristics from swine fed different levels of citrus pulp

\begin{tabular}{|c|c|c|c|c|c|c|c|}
\hline \multirow{2}{*}{ Characteristic } & \multicolumn{4}{|c|}{ Level of citrus pulp, \% } & \multirow{2}{*}{$\mathrm{CV}, \%$} & \multirow{2}{*}{ Regression } & \multirow{2}{*}{$\mathrm{P}$} \\
\hline & 0 & 10 & 20 & 30 & & & \\
\hline Final body weight, kg & 129.6 & 129.4 & 130.5 & 129.6 & 1.53 & - & $>0.1$ \\
\hline Carcass weight, $\mathrm{kg}^{(1)}$ & 105.4 & 104.2 & 102.3 & 99.8 & 2.29 & Linear & $<0.0001$ \\
\hline Carcass yield, \% & 81.8 & 81.1 & 79.2 & 77.7 & 1.51 & Linear & $<0.0001$ \\
\hline Carcass length, $\mathrm{cm}^{(1)}$ & 101.5 & 100.1 & 102.3 & 100.4 & 2.65 & - & $>0.1$ \\
\hline Backfat thickness, mm ${ }^{(1)}$ & 30.9 & 31.6 & 28.5 & 29.0 & 10.03 & - & $>0.1$ \\
\hline Loineye area, $\mathrm{cm}^{2(1)}$ & 52.7 & 56.9 & 49.0 & 46.6 & 9.28 & Quadratic & 0.0388 \\
\hline Fat area, $\mathrm{cm}^{2(1)}$ & 25.0 & 24.9 & 23.9 & 23.6 & 14.70 & - & $>0.1$ \\
\hline Fat/meat ratio $(1,2)$ & 0.48 & 0.44 & 0.49 & 0.54 & 14.68 & - & $>0.1$ \\
\hline Ham weight, kg ${ }^{(1)}$ & 16.26 & 16.32 & 15.69 & 15.22 & 4.28 & Linear & 0.0003 \\
\hline Ham yield, $\%$ & 30.86 & 31.31 & 30.69 & 30.52 & 4.27 & - & $>0.1$ \\
\hline Hot carcass weight, $\mathrm{kg}^{(3)}$ & 99.2 & 97.3 & 95.0 & 93.6 & 1.31 & Linear & $<0.0001$ \\
\hline $\mathrm{BT}, \mathrm{mm}^{(4)}$ & 15.9 & 15.9 & 14.9 & 16.2 & 14.77 & - & $>0.1$ \\
\hline $\mathrm{LD}, \mathrm{mm}^{(4)}$ & 77.4 & 78.9 & 72.2 & 68.9 & 8.61 & Linear & 0.0029 \\
\hline Carcass lean meat, $\mathrm{kg}$ & 55.9 & 55.5 & 54.9 & 52.9 & 2.48 & Linear & 0.0001 \\
\hline Carcass lean meat, $\%$ & 59.8 & 59.9 & 60.0 & 58.8 & 2.90 & - & $>0.1$ \\
\hline Bonification index, $\%$ & 116.0 & 116.1 & 116.0 & 114.4 & 1.73 & - & $>0.1$ \\
\hline
\end{tabular}

${ }^{1}$ Carcass weight and mean backfat thickness according to ABCS (Método..., 1973). ${ }^{2}$ Fat $/$ meat ratio $=$ fat area divided by loineye area. ${ }^{3}$ Carcass weight without legs and head according to Guidoni (2000). ${ }^{4} \mathrm{BT}$ and LD - backfat thickness and loin depth, respectively, measured between last and penultimate ribs, $6 \mathrm{~cm}$ far from the median dorsal line.

Table 5. Prediction equations of carcass characteristics from swine fed different levels of citus pulp

\begin{tabular}{lcccc}
\hline Variable & $\mathrm{b}_{0}$ & $\mathrm{~b}_{1}$ & $\mathrm{~b}_{2}$ & $\mathrm{R}^{2}$ \\
\hline Carcass weight, kg & 105.904 & -0.199 & - & 0.77 \\
Carcass yield, \% & 82.130 & -0.145 & - & 0.67 \\
Loineye area, cm & 53.318 & - & -0.018 & 0.37 \\
Ham weight, kg & 16.447 & -0.038 & - & 0.35 \\
Hot carcass weight, kg & 98.908 & -0.198 & - & 0.75 \\
Loin depth, cm & 79.207 & -0.324 & - & 0.24 \\
Carcass lean meat, kg & 56.271 & -0.103 & - & 0.38 \\
\hline
\end{tabular}

As consequence of slaughter standard procedures, weight at slaughtering and carcass length were not affect $(\mathrm{P}>0.1)$ by the inclusion of different citrus pulp levels to the diet. However, linear reductions on weights and yields of carcasses were observed (Table 5). Such decreasing were determined by the higher hindgut organ weights from those animals fed higher levels of citrus pulp, since great amount of NPSs determine an increase on gut secretions, high volume of the digesta, distention and hypertrophy of stomachal muscles (Low, 1989), high development of mucosal cells (Pluske et al., 1998), and hypertrophy of large intestine (Wyatt et al., 1989), resulting in higher weight of these organs. While Fraga et al. (2008) did not observe 
inferior carcass yield due to the inclusion of $19 \%$ rice hull to the diet of swine averaging $130 \mathrm{~kg}$ BW swine, Scipione et al. (1991) detected significant carcass yield reduction in animals fed sugar beet pulp silage and slaughtered at $144 \mathrm{~kg}$. Pluske et al. (1998) related negative correlation between NSPs intake and carcass yield. Under commercial point of view, this relation is indicative that exist some limitations on the use of rich-NSP feedstuffs to swine diet, as the remuneration of the producer is based on carcass characteristics and not on viscera, like liver and pancreas.

Beyond backfat thickness and fat area decreasing $(\mathrm{P}<0.001)$, two important characteristics of pork carcass typification, inclusion of citrus pulp to the diet determined a quadratic effect on the loineye area with higher loin development at $8.0 \%$ of addition (Table 5). Candek-Potokar et al. (1999), testing the effect of $30 \%$ quantitative feed restriction upon loineye area of swine slaughtered at $130 \mathrm{~kg} \mathrm{BW}$ did not observe higher development of this muscle, concluding that high level of quantitative feed restriction may leave to a deficiency on nutrients required for muscular grow, being the main cause of short size of muscular fiber.

A linear decrease on ham weights $(\mathrm{P}=0.0003)$ as function of higher levels of citrus pulp addition to the diet were observed (Table 5), but ham yields were not affected $(\mathrm{P}>0.1)$. Considering the finest part of the pork carcass, the ham of 130kg-BW swine yielding only $30 \%$ commercially represent at least $60 \%$ of the meat value as they are destined to the processing of smoke-cured products with high aggregate price values. Thus, it is vital to use a feed restriction program that promote an improvement on carcass quality, maintaining at least good ham yield, result herein achieved.

For carcass typification, hot carcass weight (HCW), backfat thickness (BT), and the loin depth (LD) should be taken into consideration (Zagury, 2002). Linear decrease as function of dietary citrus pulp use for $\mathrm{HCW}(\mathrm{P}=0.0001)$ and LD ( $\mathrm{P}=0.0029)$ were observed, but not for $\mathrm{BT}$ $(\mathrm{P}>0.1)$. Considering these three characteristics (BT, HCW, and LD) to lean meat quantification $(\mathrm{kg})$, a linear decrease $(\mathrm{P}=0.0001)$ was detected (Tables 4 and 5) as an indicative that qualitative feed restriction by citrus pulp inclusion was not efficient.

Table 6 shows values relative to qualitative meat characteristics. Prediction equations of $\mathrm{pH} 24 \mathrm{~h}$ and color parameters of muscles are found in Table 7. Notwithstanding the non effect $(\mathrm{P}>0.1)$ of dietary citrus pulp level for $\mathrm{pH} 45 \mathrm{~h}$ of Longissimus and Semitendinosus muscles, a positive linear trend $(\mathrm{P}<0.05)$ for $\mathrm{pH} 24 \mathrm{~h}$ measured on the same place was registered (Table 7).

Table 6. Mean values and coefficients of variations (CV) of qualitative meat characteristics from swine fed different levels of citrus pulp

\begin{tabular}{|c|c|c|c|c|c|c|c|}
\hline \multirow{2}{*}{ Qualitative characteristic } & \multicolumn{4}{|c|}{ Level of citrus pulp, $\%$} & \multirow{2}{*}{$\mathrm{CV}, \%$} & \multirow{2}{*}{$\begin{array}{c}\text { Regressi } \\
\text { on }\end{array}$} & \multirow{2}{*}{$P$} \\
\hline & 0 & 10 & 20 & 30 & & & \\
\hline pH45' Longissimus & 6.12 & 6.13 & 6.11 & 6.32 & 3.62 & - & $>0.1$ \\
\hline pH45' Semitendinosus & 6.06 & 6.04 & 6.11 & 6.23 & 2.42 & - & 0.055 \\
\hline pH24h Longissimus & 5.47 & 5.49 & 5.50 & 5.60 & 1.15 & Linear & 0.0005 \\
\hline $\mathrm{pH} 24 \mathrm{~h}$ Semitendinosus & 5.45 & 5.45 & 5.50 & 5.53 & 0.87 & Linear & 0.0021 \\
\hline Drip loss, $\%$ & 12.44 & 12.55 & 11.48 & 9.11 & 5.32 & - & 0.0549 \\
\hline $\mathrm{L}^{*}$ value & 59.01 & 61.56 & 57.89 & 55.70 & 5.54 & Linear & 0.0307 \\
\hline $\mathrm{a}^{*}$ value & 8.73 & 8.91 & 7.05 & 6.95 & 14.38 & Linear & 0.001 \\
\hline $\mathrm{b}^{*}$ value & 7.19 & 6.74 & 5.29 & 4.60 & 31.84 & Linear & 0.0024 \\
\hline Cooking loss (evaporation), \% & 28.77 & 29.85 & 27.32 & 27.52 & 10.25 & - & $>0.1$ \\
\hline Cooking loss (drip), $\%$ & 12.45 & 12.55 & 11.48 & 9.11 & 23.80 & - & $>0.1$ \\
\hline Cooking (total), $\%$ & 30.95 & 31.35 & 29.68 & 29.64 & 9.51 & - & $>0.1$ \\
\hline Shear force, $\mathrm{kgf} / \mathrm{cm}^{2}$ & 2.59 & 2.92 & 2.99 & 2.84 & 16.28 & - & $>0.1$ \\
\hline WHC, $\%^{(1)}$ & 68.45 & 68.42 & 70.55 & 71.82 & 4.07 & - & $>0.1$ \\
\hline TBARS, mg/kg ${ }^{(1)}$ & 0.58 & 0.50 & 0.46 & 0.46 & 44.81 & - & $>0.1$ \\
\hline
\end{tabular}

WHC: water holding capacity; TBARS - thiobarbituric acid reactive substances. 
Table 7. Prediction equations of qualitative meat characteristics from swine fed different levels of citus pulp

\begin{tabular}{lccc}
\hline Variable & $\mathrm{b}_{0}$ & $\mathrm{~b}_{1}$ & $\mathrm{R}^{2}$ \\
\hline $\mathrm{pH} 24 \mathrm{~h}$ Longissimus & 5.371 & +0.004 & 0.31 \\
$\mathrm{pH} 24 \mathrm{~h}$ Semitendinosus & 5.361 & +0.002 & 0.29 \\
$\mathrm{~L}^{*}$ value & 60.584 & -0.136 & 0.13 \\
$\mathrm{a}^{*}$ value & 9.306 & -0.085 & 0.28 \\
$\mathrm{~b}^{*}$ value & 7.634 & 0.116 & 0.24 \\
\hline
\end{tabular}

Citrus pulp inclusion to the diet did not affect drip losses of the carcasses. Despite the superior results obtained $(11.4 \%)$ for this characteristic, higher than the desired 5\%, this augment should not be attributed to the addition of the citrus pulp to the diet since all treatments presented similar values. The amplitude of the values found by Souza et al. (1998) for drip loss was from 4.5 to $10.4 \%$, showing that many factors could influence this meat characteristic, e.g., correct application of electric insensibilization, interval between insensibilization time, bleeding, and carcass refrigeration.

The use of citrus pulp altered color parameters, being observed linear reduction $(\mathrm{P}<0.05)$ of $\mathrm{L}^{*}$, $\mathrm{a}^{*}$, and $\mathrm{b}^{*}$ values (Table 7 ) as the dietary levels of the feedstuff increased. Lower color values are indicative of darker meat, less red, and less yellow, respectively (Warris, 1995). Fraga et al. (2008) also observed reduction of the $\mathrm{a}^{*}$ and $\mathrm{b}^{*}$ values, but not $\mathrm{L}^{*}$, with the inclusion of rice hulls to diets of $130-\mathrm{kg}-\mathrm{BW}$ swine, probably due to the reduction of dietary pigments as consequence of the low level of corn in the ration. However, Martelli et al. (1999) did not observed any effects of the use of dietary sugar beet silage upon $\mathrm{pH}$ or color values from $160-\mathrm{kg}$ BW swine meat.

As swine show a tendency of increasing subcutaneous and intramuscular lipid depositions with increasing weight, slaughtering heavier animals can result carcasses with higher intramuscular fat content, altering $b^{*}$ color parameter (Varnam and Sutherland, 1995). According to Joo et al. (2002), alterations of the $\mathrm{b}^{*}$ values indicate modification on fat acid composition of the intramuscular fat.

Besides the diet, feed restriction may also modify meat color parameters. According to CandekPotokar et al. (1999), 30\% of feed restriction to swine slaughtered at $130 \mathrm{~kg}$ BW affected muscular configuration of the loin, showing higher relative area occupied by red muscular fiber of slow contraction, and decrease of $a^{*}$ and $\mathrm{b}^{*}$ values as consequence.

For cooking loss characteristics (evaporation, drip, and total), no effects of dietary citrus pulp inclusion were observed ( $\mathrm{P}>0.1)$. Mean values of total cooking losses observed in this experiment $(30.4 \%)$ were similar to $32.3,30.8$, and $27.8 \%$, obtained by Hodgson et al. (1991), Pires et al. (2002), and Bridi et al. (2006), respectively.

As the shear force, mean result was $2.83 \mathrm{kgf} / \mathrm{cm}^{2}$, but no differences on meat tenderness were observed. Bridi et al. (2006) evaluating addition of ractopamine to the diet of $100-\mathrm{kg}-\mathrm{BW}$ slaughtered swine found $3.44 \mathrm{kgf} / \mathrm{cm}^{2}$, which is superior to the value here obtained. On the other hand, Latorre et al. (2002) reported values around to $2.70 \mathrm{kgf} / \mathrm{cm}^{2}$ for $133-\mathrm{kg}-\mathrm{BW}$ animals in a study of pork meat quality.

Respecting to water holding capacity, no effects of inclusion of different levels citrus pulp to diet were detected. Fraga et al. (2008) verified no effects on the water holding capacity in an evaluation of qualitative feed restriction program, registering mean value of $64.8 \%$ which is similar to the mean $69.8 \%$ here obtained.

Lipid oxidation is also an important characteristic for the evaluation of pork carcass, as the main consequence is a modification on the flavor of the meat with the emergence of rancidity, causing depreciation or refusal of the meat for the consumer and/or meat processor (Silva et al., 1998). According to Sabarense (2003), the diet can modify the meat fat acid profile, and the tendency of its lipid oxidation. Lipid oxidation indexes (TBA) here observed are indicative that the inclusion of citrus pulp did not cause $(\mathrm{P}>0.1)$ high peroxidation and/or high level of products resulting of its degradation, such as malonaldeyde. The TBA value here obtained $(0.50 \mathrm{mg} / \mathrm{kg})$ is similar to $0.52 \mathrm{mg} / \mathrm{kg}$ 
found by Joo et al. (2002) evaluating the inclusion of conjugated linoleic acid to diet of 105-kg-BW slaughtered swine. Being a comparative analysis of the evaluation of the lipid stability under refrigeration, the inclusion of the citrus pulp in program of feed restriction did not negatively affect meat quality nor shorten its shelf time.

\section{CONCLUSION}

The citrus pulp addition in qualitative feed restriction program for swine slaughtered at $130 \mathrm{~kg}$ BW may not be effective. However, as no deleterious effects upon meat qualities were observed, citrus pulp can be used as an alternative feedstuff for finishing swine.

\section{REFERENCES}

BRIDI, A.M.; OLIVEIRA, A.R.; FONSECA, N.A.N et al. Efeito do genótipo halotano, da ractopamina e do sexo do animal na qualidade da carne suína. Rev. Bras. Zootec., v.35, p.2027-2033, 2006.

BRUSS, M.L. Lipids and ketones. In: MANERO, J.J.; HARVEY, J.W.; BRUSS, M.L (Eds). Clinical biochemistry of domestic animals. San Diego: Academic, 1997. p.83-15.

CANDEK-POTOKAR, M.; LEFAUCHEUR, L.; ZLENDER, B. et al. Effect of slaughter weight and/or age on histological characteristics of pig Longissimus dorsi muscle as related to meat quality. Meat Sci., v.98, p.195-203, 1999.

FÁVERO, J.A.; GUIDONI, A.L.; BELLAVER, C. Predição do índice de valorização de carcaças suínas em função do peso e do percentual de carne. In: CONGRESSO DA ASSOCIAÇÃO BRASILEIRA DE VETERINÁRIOS ESPECIALISTAS EM SUÍNOS, 8., 1997, Concórdia. Anais... Concórdia: Embrapa-CNPSA, 1997. p.405-406.

FRAGA, A.L.; THOMAZ, M.C.; KRONKA, R.N. et al. Restrição alimentar qualitativa para suínos com elevado peso de abate. Rev. Bras. Zootec., v.37, p.869-875, 2008.

FRAGA, A.L.; THOMAZ, M.C.; KRONKA, R.N. et al. Qualitative feed restriction for heavy swines: effect on digestibility and weight of organs of digestive tract, and environmental impact of feces. Arq. Bras. Med. Vet. Zootec., v.61, p.1353-1363, 2009.
GUIDONI, A.L. Melhoria dos processos para tipificação de carcaças suínas no Brasil. In: CONFERÊNCIA INTERNACIONAL VIRTUAL SOBRE QUALIDADE DE CARNE SUÍNA, 1., 2000, Concórdia. Anais...Concórdia, Embrapa, 2000. Disponível em: <http://www.cnpsa.embrapa.br/pork>. Acessado em: 12 fev. 2006.

HODGSON, R.R.; DAVIS, G.W.; SMITH, G.C. et al. Relationships between pork loin palatability traits and physical characteristics of cooked chops. J. Anim. Sci., v.69, p.4858-4865, 1991.

JOO, S.T.; LEE, J.I.; HA, Y.L. et al. Effect of dietary conjugated linoleic acid on fatty acid composition, lipid oxidation, color, water-holding capacity of pork loin. J. Anim. Sci., v.80, p.108112, 2002.

KREUZER, M.; HANNEKEN, H.; WITTMANN, $M$. et al. Effects of different fibre sources and fat addition on cholesterol and cholesterol-related lipids in blood serum, bile and body tissues of growing pigs. J. Anim. Physiol. Anim. Nutr., v.86, p.57-73, 2002.

LATORRE, M.A.; LÁZARO, R.; VALENCIA, D.G. et al. The effects of gender and slaughter weight on the growth performance, carcass traits, and meat quality characteristics of heavy pigs. $J$. Anim. Sci., v.82, p.526-533, 2002.

LEE, C.Y.; LEE, H.P.; JEONG, J.H. et al. Effects of restricted feeding, low-energy diet, and implantation of trenbolone acetate plus estradiol on growth, carcass traits, and circulating concentrations of insulin-like growth factor (IGF)-I and IGF-binding protein -3 in finishing barrows. $J$. Anim. Sci., v.80, p.84-93, 2002.

LEHNINGER, A.L.; NELSON, L.D.; COX, M.M. Princípios de bioquímica. 8.ed. São Paulo: Sarvier, 1995. 839p.

LOW, A.G. Secretory responses of the pig gut to non-starch polysaccharides. Anim. Feed Sci. Technol., v.23, p.55-65, 1989.

MARTELLI, G.; SARDI, L.; PARISINI, P. et al. The effects of sugar beet pulp silage (PBPS) added with vinasse in heavy pig production. Zootec. Nutr. Anim., v.26, p.219-225, 1999.

MÉTODO brasileiro de classificação de carcaças. Estrela, RS: Associação Brasileira de Criadores de Suínos, 1973. 17p. (Publ. Tec. 2).

NUTRIENT requirement of swine. 6.ed. Washington: National Academy of Sciences, 1998. 190p. 
PIKUL, J.; LESZCZYNSKI, D.E.; KUMMEROW, F.A. Evaluation of tree modified TBA methods for measuring lipid oxidation in chicken meat. J. Agric. Food Chem., v.37, p.1309-1313, 1989.

PIRES, I.S.C.; ROSADO, G.P.; AZEREDO, R.M.C. et al. Composição centesimal, perdas de peso e maciez do lombo (Longissimus dorsi) suíno submetido a diferentes tratamentos de congelamento e descongelamento. Rev. Nutr., v.15, p.163-172, 2002.

PLUSKE, J.R.; PETHICK, D.W.; MULLAN, B.P. Differential effects of feeding fermentable carbohydrate to growing pig on performance, gut size and slaughter characteristics. Anim. Sci., v.67, p.147-156, 1998.

ROSTAGNO, H.S.; ALBINO, L.F.T.; DONZELE, J.L. et al. Tabelas brasileiras para aves e suínos Composição de alimentos e exigências nutricionais. Viçosa: UFV, 2005. 141p.

SABARENSE, C.M. Avaliação do efeito de ácidos graxos trans sobre o perfil de ácidos graxos teciduais de ratos que consumiram diferentes teores de ácidos graxos essenciais. 2003. 130f. Tese (Doutorado) - Faculdade de Ciências Farmacêuticas, Universidade de São Paulo, São Paulo.

SAMBROOK, I.E. Studies on the flow and composition of bile in growing pigs. J. Sci. Food Agric., v.32, p.781-791, 1981.

SCIPIONE, R.; SARDI, L.; BARCHI, D. et al. Elevate quantità di insilati nell'alimentazione del suino pesante: effetti sulle performance di acrescimento e di macellazione. Riv. Suinicolt., v.32, p.71-78, 1991.

SILVA, F.A.M.; BORGES, M.F.; FERREIRA, M.A. Métodos para avaliação do grau de oxidação lipídica e da capacidade oxidante. Quím. Nova, v.22, p.175-184, 1998.
SILVEIRA, E.T.F. Valorização da carcaça suína e suas implicações na cadeia produtiva de suínos. Porkworld, v.2, p.32, 2003.

SOUZA, N.D.; WARNER, R.D.; DUNSHEA, F.R. et al. Effects of on-farm and pre-slaughter handling of pigs on meat quality. Aust. J. Agric. Res., v.11, p.1021-1025, 1998.

SUBPRODUTOS da laranja. São Paulo: Associação Brasileira de Exportadores de Cítricos, $2006 . \quad$ Disponível em: <www.abecitrus.com.br/subprodutos_br.html\#oess enciais>. Acessado em: 5 Out. 2006.

VARNAM, A.H.; SUTHERLAND, J.P. Meat and meat products: technology, chemistry and microbiology. London: St. Edmundsbury Press, 1995. p.98-107.

WARRIS, P. Considerations on methods of assessing pork meat quality. In: CONFERÊNCIA INTERNACIONAL SOBRE CIÊNCIA E TECNOLOGIA DE PRODUÇÃO DE SUÍNO, 1., 1995, Campinas. Anais... Campinas: CTC, 1995. p.91-108.

WHITTEMORE, C. Nutritional manipulation of carcass quality in pigs. In: COLE, D.J.A. Recent development in pig nutrition. 2.ed. Nottingham: Nottingham University, 1993. p.13-19.

WYATT, G.M.; HORN, N.; GEE, J.M. et al. Intestinal microflora and gastrointestinal adaptation in the rat in response to non-digestible dietary polysaccharides. Br. J. Nutr., v.60, p.197-207, 1989.

ZAGURY, F.T.R. Abate de suínos pesados: vale a pena? Porkworld, v.1, p.30-34, 2002. 